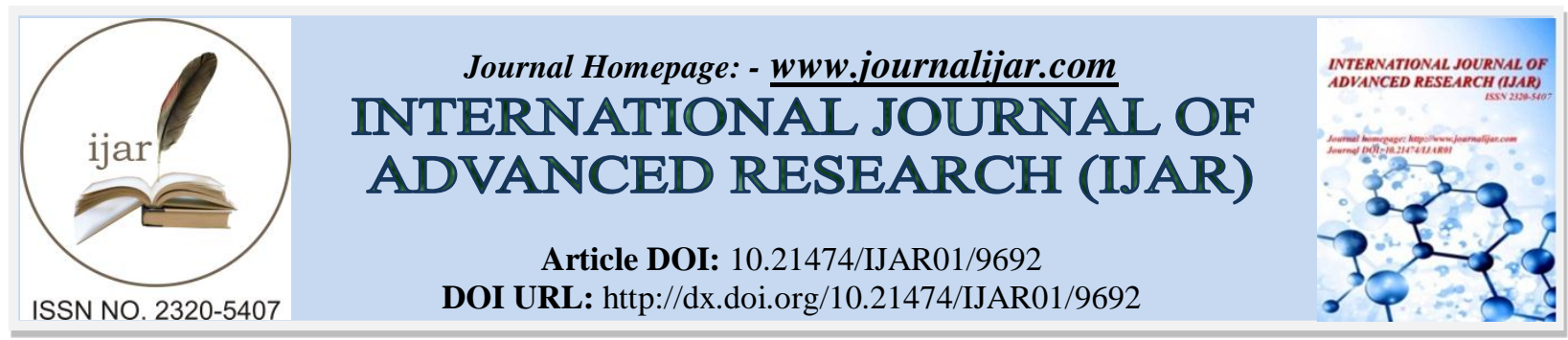

RESEARCH ARTICLE

\title{
ILYAS EFENDIYEV'S DRAMATURGIC LANGUAGE ASPECTS AND ITS FORMATION ISSUES.
}

Flora Namazova Kamran.

Assistant Professor of Department of Humanities of Mingechevir State University, PhD in Linguistics.

\section{Manuscript Info}

Manuscript History

Received: 08 July 2019

Final Accepted: 10 August 2019

Published: September 2019

\section{Key words:-}

the great Azeri writer Ilyas Efendiyev, Ilyas Efendiyev's drama language features, Ilyas Efendiyev's drama language formation, dramaturgy language potential, dramaturgy language characteristic features, formation and development of lyrico psycological drama language.
Abstract

The main aim of the research is to investigate the dramaturgic language aspects and their formation issues in creation of Ilyas Efendiyev - one of the outstanding classicists of Azerbaijan literature of XX century. Ilyas Efendiyev left mark in history as the literary giant with sufficient deep devotion to national and spiritual peculiarities. He left a deep imprint on the theatre and dramaturgy history of Azerbaijan by his numerous dramatical pieces, and achieved creation of vivid image of the characters. The aspects of dramaturgic language of the great writer and the special features of dramatic genre were investigated in the article.The potential and aspects of dramaturgic language were revealed skilfully by means of different characters's dialogues, the importance of chracteristic features of this language was pitched to society. Ilyas Efendiyev gave particular importance to the language and proficiency issues in his dramaturgy, and the author's responsibility for language features safety was brought to the fore. The greatest master author's dramatic pieces are imbued with grass-roots language genius, and he was able to show its aspects by making ample use of his own individual lyrico-psychological creation style. The analyses on these were adduced, and there was shown the great writer's achievement in implementation of spoken language common to Azeri nation to the drama language in his dramatic pieces. There was a elucidated how the author benefited from the subtilities of the rich language common to his nation. The subtilities of the grass-roots language and features of the drama language were harmonized on the basis of lexis of his drama pieces, and as a result the great author formed a drama language reflecting the national spirit. The connexity of language and masterfulness issues, their philosophy and approaches in dramaturgy were investigated. Ilyas Efendiev's role in the formation and development of lyrico-psycological drama language was characterized in the article. The estimation units of the greatest writter's drama pieces were indicated. The article tells about characterstic features ad methods of Ilyas Efendiyev's work on drama language. The reviewed issues were summarized, the scientific polemic on different writters' approaches to the mentoned issues were encouraged, scientific practical commitments were formed in the article. There was given the writter's position on drama language aspects and their formation features in Ilyas Efendiyev's creativity.

Copy Right, IJAR, 2019,. All rights reserved. 


\section{Introduction:-}

The processes of writing the article on Ilyas Efendiyev's drama language aspects and formation issues being both hard and honorabe work was important as moral duty for me. In the drama pieces of one of the great writers in Azerbaijan literature the wide place was given to language features and special aspects. Doubtless the drama pieces of the great writer were studied well, his drama language aspects were sufficiently appraised, research works were written, different opinions were given. But what with all these we consider important the highlighting of Ilyas Efendiyev's language in drama pieces, the review of issues of national spirit sipping to these writings by meas of language nuances and potentials through the wider prism and their analysis. Azeri language was prosecuted and underwent many prohibitions during its development process. The Azeri alphabet also changed seeral times. During the soviet union period of Azerbaijan - while being a part of former USSR (1920-1991) - the country was deprived of developing its grass-roots language. At this particular conditions Ilyas Efendiyev made possible to save and develop the grass-roots language. The writer reached the formation and development of drama language reflecting the national connectivity by implementation of his native language and its features in the lexis of drama. In the drama pieces of the great writer the language and creativity issues were highlighted, the issues of language development, its protection, sufficient usage of its potential were kepe front and centre. One of his important achievments is formation of lyrico-psychological drama language and huge volume works during its development. Ilyas Efendiyev showed historical achievments by sipping the grass-roots language nuances into dramaturgy language with the aim of estimation of his nation'smoral-ethical values, protection of social lifes features of the society, and characterization of traditions. The remarkable thing is that the language is important and irreplaceable tool for belles-lettres. A language as a tool can materially affect the idea-content quality of belles-lettres. The belleslettres language takes the lead in the styles system of literary language, and belles-lettres language is the core of literary language. Belles-lettres play a huge role in formation and development of literary language, it enriches the literaty language. Belles-lettres is a single entity, it expresses its originality, essence and uniqueness in its coherence as a unique text. The whole structure of true art of declamation sample and consolidaton of relations systems is always in the purview. 'In the belles-lettres a language supports the writer's idea expression not only with its logical idioms, but also with its form, external influence, harmony and music' (Mammad Arif, 1967). From the language point of view the literary speech is unlimited, the imaginative lexis is specific to this speech. The linguistic study of belles-lettres which is the basis of the artistic style is always one of the most topical issues (Sibagatov R.G., 1983). The drama language has a strong and determining impact on formation and development of drama style of our artistic language. From this point of view the drama language of Azerbaijan national writer Ilyas Efendiyev is an example of great skill. The great Azeri dramatists Ilyas Efendiyev had a rich and meaningful creativity path. He created "Ilyas Efendiyev's theatre' with his twenty four plays. He brought a new spirit and breath to Azeri literature with these dramas. The writer formed the lyrico-psycological style in our dramaturgy and continued its traditions. Ilyas Efendiyev's drama pieces are not only on idea-content and sociology plan but are also modern by thier artistic language and style. Azeri theatre formed its repertoire on this dramaturgy during some decades of the previous century. One of the main problems facing the analysis of artistic language, especially the drama language, is determinaion of author's apporach and connectivity to the grass-roots language, the uniqueness of his style and individuality degree. This issue is in harmony with master's view. One of our important aims in the artice is invetigation of the writer's being a great dialogue master. It is possible to realize the possibilities of truth expression in heroes' imaginative speeches by determining the mastery searching in this field. Thus, the novel features in Ilyas Efendiyev's dramaturgy were quite high. This innovation is expresses in the characters' and heroes' moralpsychological tension, emotions, expressive-emotional speech act, dramatic movements and speeches and etc. which he created. By extensive study of Ilyas Efendiyev's drama language we shed the light on powerful capabilities of Azeri national spoken language and ways of attraction of these capabilities to the drama language. I adventured an opinion and disclosed my considerations on these features and formation issues of drama language formed by Ilyas Efendiyev. I express gratitude in advance to all investigators, linguists, theorists of literature who will show initiative in scientific debates, polemics, and discussions.

\section{Issues covered in the article}

The issues covered in the article are reated to Ilyas Efendiyev's drama language features and development issues. For that end the complex study of language and style features of the drama pieces by great national writer and dramatist Ilyas Efendiyev has been set as a goal and task in the article. Among them there are most of all the exposure and grounding of writer's stagecraft, determining the lexical wealth of his drama pieces language, drama genre, and characteristic features of drama language, the reveal of characteristic features of drama language 
developped and enriched by Ilyas Efendiyev, reveiw of the language and mastery issues in these processes, especially evaluation of great writer's role in formation and development of lyrico-psycological language, and writer's criteria and approaches to the language factors in his own compositions.

\section{Theoretical and practical importance of the text}

Theoretical importance of the article - Ilyas Efendiyev's role in development of Azeri literary language, the writer's achievments in influence of spoken language on literary language are directly connected to important features of his creativity in the improvment of literary language norms and its systematization. In theoretical aspect it is possible to use contaned in the article contributions, analysis, and scientific considerations as discussion and theoretical and methodological bases in the research processes conducted in this field of linguistics. Besides this the theoretical materials of the article enriches the theory of drama language and develop it, the scientific materials of this field can attract interest of Azeri and world scientists. Practical importance of the article - is associated with the consistent linguistic analysis of the features of the drama language. Thus, contained herein scientific-practical materials and theoretical-methodological contributions hold the potential of wide implementation in education and research processes.

\section{Methods and approaches:-}

The simultaneous research method was used in preparation of the article. Besides this the priority was given to imaginative-linguistic and stylish analysis method, and structural functional method. An adequate relation was shown thoughts and views of writers, critics and linguists who conducted the ressearches in this field, generalizations were conducted. The main idea of the article became the formation of author's view on Ilyas Efendiyev's drama language characteristics and issues. The writer made efforts to form his ideas and considerations alongside with assessing the researches on Ilyas Efendiev's drama literature characteristics and formation issues.

\section{Possibility on contribution which can be given by the article to the world linguistics, and philology sciences in a whole. \\ The writer considers that the research materials given in the article and generalized contributions from the scientific polemic point of view are of definite scientific practical value, and can enter the circle of interests in the future researches of the factors acting in this direction in the world. Thus, linguistics-stylish features of Ilyas Efendiyev's dramaturgy are researched as monography on all levels of the language for the first time. I hope that, the research of drama language aspects and its formation issues this way will contribute and will be fruitful for Azerbaijan and world linguistics science, and philology science in a whole.}

\section{The level of studying the problem and the literature review}

In relation to reseach of the issues mentioned in the article it can be mentioned that many reseach works were conducted on Ilyas Efendiyev's heritage, his novels, narratives and also drama pieces. Monographies and artiles were written in this direction. Ilyas Efendiyev's drama language aspects and theorertical basis were reviewed in researches of many critics, researchers and linguists. Of course first of all it is necessary to mention the great tribute of former nationl writer Elchin Efendiyev, who grew up and studied in the very heart of Ilyas Efendiyev's house, in environment of formation and development of the literary heritage, and Timurchin Efendiyev, one of the constant researches of Ilyas Efendiyev's heritage. The characteristic features of Ilyas Efendiyev's drama language, characteristic features of drama language, personality portrait of the great writer, his talent lines which took place in drama pieces were most of all researched in Elchin Efendiyev's work (Elchin, 2000; Elchin, 2002). The issues reviewed in great write's drama pieces, characteristic features of the drama genre and drama language, the other characteristic features of his creativity, especially the literary problems in romantic dramatury, and at the same time the methods of Azeri dramaturgy were given in researches of Timurchin Efendiyev (Efendiyev T., 1999; Efendiyev T., 2002). The specific features nd importance of the word and the language was in the spotlight of Mammad Arif's researches (Mammad Arif, 1967; Mammad Arif, 1968). Professor Abdulazal Demirchizadeh brought to the fore the language, its characteristics and characteristic features analysing the creativity of great Azeri writer and mastermind Akhundov M.F. (Demirchizadeh A., 1941).

The language and its features, formation of drama language in Ilyas Efendiyev's drama pieces and the role of the great write in all these processes saw the true value in researches of professors Yashar Garayev and Mehdi Mammadov (Garayev Y., 1972; Garayev Y., 1987; Mammadov M., 1968; Mammadov M., 1965). Academician Bekir Nabiyev also voiced his attitude regarding the issues in this field (Nabiyev B., 2000). Conducting the constant researches in the fild of dramaturgy Ilham Rahimli gave a systematic reveal of drama genre and characteristic features of drama 
language (Rahimli I., 1984). In the works of professor Yahya Seyidov the aspects of Ilyas Efendiyev's drama language and the issues in regards of it were analysed (Seyidov Y., 1975 and Seyidov Y., 2008). Aida Salahova gave special consideration to poetic colors and word value in Ilyas Efendiyev's creativity (Salahova A., 1984).

The literary language, behavior, and moral and ethical values of the characters in Ilyas Efendiyev's drama pieces were expressed more extremely by means of the language, and all these had a great importance in drama language formation. The great Azerbaijan writer Suleyman Rahimov drew special attention to expression of Ilyas Efendyev's attitude to the language and its characteritic features, and his standing as a write and a citizen complimented by all these (Rahimov S., 1974). The great national poet and professor Bakhtiyar Vahabzadeh formed the thoughts of valuable scientific and practical significance about language, its ntionalism, national colors. According to him Ilyas Efendyev's characters are more significant, they reassure us by their speeches (Vahabzadeh B., 1986). In a number of his works Amin Efendiyev estimated the different aspects of Ilyas Efendiyev's creativity and also estimated him as the great dramatist creating the best examples of lyrico-psychological style. According to him the great master was selfrigorous, and also had a high demand for language-related approaches (Efendiyev A., 1996; Efendiyev A., 2000; Efendiyev A., 2002). Ilyas Efendiyev made calls to the hands stretching to the national-moral values and issues causinig the trouble to society and people by means of drama pieces language. For this, he succeeded in using the drama language (Allahverdiyev M., 1990).

The great writer's approach to the language issues, aspects, possibilities in the drama genre in this issues through personalty prism in his dramaturgy was expressed in the works of several researchers (Hajiyev D., 1983; Ismayllov Y., 1991; Sultanlı A., 1964; Safiyev A., 1999). Besides, the write's approach issues to the characteristic aspects of drama language and conformity with a literary laws did not escape from the review of researchers (Hajiyev A., 1986). The specific features of Ilyas Efendiyev's creativity as a prose writer and dramatist, the special aspects of his drama language took place in research works of several researchers suchh as A.Tahirli, A.Akhundov, A.Mirahmadov and S.Shahbazova (Tahirli A. 2003; Akhundov A., 2003; Mirahmadov A., 1999; Shahbazova S., 2002).

The uniqueness of the artistic language, style differences, linguistic analysis of the literary text, characterization speech problems in a text were reflected in the researches of A.Telmangizi, Z.Mammadova, A.Gurbanov and A.Dadashov (Telmangızı A., 2003; Mammadova Z., 2008; Gurbanov A., 2005; Dadashov A., 2005). In their scientific works H.Abbaszadeh, S.Abbasova and V.Yusifli gave ideas and cosiderations on usage of dilin spesifik cəhətlərinin üstünlüyünü in literary form by means of the characters of Ilyas Efendyev's drama pieces, and on he modern spects connected with this (Abbaszadeh H., 2006; Abbasova S., 2007; Yusifli V., 2006).

Taking into account the characteristic features of the language in drama pieces and other artistic genres, the functions and features of the language, speech assessment were in the spotlight of several researchers' scientific works (Sherba L., 1939; Yefimov A., 1954; Vinogradov V., 1959; Kozhevnikova K., 1970; Khrabchenko M., 1986; Politova L., 1992). Another group of researchers wrote and defended dissertations on Ilyas Efendiyev's creativty, which includes the heroic issues of the characters in lyrico-psychological drama pieces, language and style approaches (Nasirov G., 1967; Salmanov I., 1983; Verdiyev V., 1984; Alizadeh M., 1990).

In recent times Ilyas Efendyev's creatvity, including main misson of his drama pieces, language sourses, implementation issues of live spoken language in dramaturgy, skills and features of being a dialogue master were expressed in scientific and research works of a group of researchers such as M.Ayyubgizı, M.Huseynova, T.Mammadova, M.Mammadova, G.Zeynallı and professor Sh. Alıshanlının (Ayyubgızı M., 2004; Tinayeva Ә., 2006; Huseynova M., 2009; Mammadova T., 2014; Mammadova M., 2014; Zeynallı G., 2015; Alishanli Sh., 2017).

Alongside with noting the work of writers, scentists and researchers, the language aspects of Ilyas Efendiyev's dramaturgy, its characterstic features, issue of skillful language use in great writer's drama pieces, the master writer's role in formation and development of lyrico-psychological language made the wider and more complex researches in thiese fields important. Taking in to account all these the issues in those directions, their characteristic features and aspects are researched in the article.

\section{Analysis of Ilyas Efendiyev's drama language aspects}

In the researches related to the literary theory it is shown that 'drama' term means movement, action and dynamics in Greek. Movement is one of the main features of drama pieces. More specifically here the visual description of life processes by means of dialogues throughout the development of the storyline is used as a basis (Aliyev M., 2009; Mammad Arif, 1967). Drama pieces are fundamentally different from the other genres. As recently as 19th century the great thinker Akhundov M.F. differentiated the drama genre which he brought to our literature from the other 
genres. Akhundov M.F. who knows that the exposure of the type with his own language is a specific aspect for the play advising to take this feature into account writes in his play named 'Ashraf khan': 'Every time due to such things by different phrases Ashraf khan must report back to those who listens to his work and actions in Arabia' (Demirchizadeh A., 1941). As in other literary genres dramaturgy also was an important sourse of factors always expressing the wealth and colorfulness of live grass-roots language and its compliance. In such works the most general and the most private character of the language is hidden. A word and a phrase in drama language can gain a new meaning and meaning subtility, the color of style of words and phrases changes. For this reason onthe characteristic features of drama pieces are their language and style. This language and style is the exact litetary language of the period of drama appearance. Akhundov M.F. highly appreciated actively influencing the morality, desires and ideas of viewers and readers drama art more than the other types of art and wrote: 'The aim of drama art is to improve people's morality, to direct the readers and listerners' (Akhundov M.F., 1951; Politova L.V., 1992). Indeed, the drama art teaches people self-awareness, hate the ugliness and wakes emotions of communal affiliation (Allahverdiyev M.G., 1990). Dramaturgy is one of the styles of artistic works. Its language can be studied not only in usage plan but also as a subject matter. Because 'the language on its own is inescapable part of artistic reality, and this reality allows the writer to perform some or all of his creative abilities directly and even in a complex way'. (Kozhevnikova K., 1970). It is clear that there is no author language-dramatist language in dramaturgy. The ideas and thoughts in stage creations as distinct from other genres are expressed only in language of figures. Here each figure speaks in his own voice, expresses his attitude to the events and stories, time and period, and people; he uses each word freely as he wants; reveals his ideology by the words and phrases, expresses his wishes and thoughts. Great masters always give special attention to personalization and typing of the figures' language and speech. In dramturgy a word carries a characteristic of action and conflict. Each single lexic image brings to action, burns up internally, overwhelms, prepares the opponent to respond to the queston. That is why in stage creation the use of word, composition of a dialogue and a monologue requires big talent of dramatist (Gurbanov A.M., 2005). A dialogue condition can be considered an important basis for speech.... the most valuable sourse for analysis of dialogue speech is drama text (Mammadova Z., 2008). The speech in drama pieces is expressed as a system of composition combination of dialogue parts in a full artistic structure. For this reason the analysis of drama language first of all should be directed on artistic traditions expressed in dialogue form (Vinogradov V.V., 1959). The characteristic features of a character and a feature are revealed in these conditions in particular. One of the main features of the drama pieces is that in such pieces there is no description of the author. As an author can not interfere the dvelpment of the actions, the inner world of the figures, their actions and factors, their mood, personality and skills are expressed by their own speech. 'The artwork prossess of live realities in dramaturgy' and 'Conflict laying in the basis of drama' draw attention as the main features of this genre. (Dadashov A., 2005). In Azerbaijan, they began to research the dramatic language in the 1940s. A. Damirchizadeh wrote the booked named 'M.F.Akhundov's language and about M.F.Akhundov's language' and spoke about the drama language in it. The author gave interesting scientfic information about the language of the M.F.Akhundov's plays named 'Haji Gara', 'SarguzeshtiVaziri-Khani-Lankaran', 'Monsieur Gordan and Dervish Mastali shah'. A.Damirchizadeh expressed comic technics and comic language in a compact manner with the reference to several methods, such as type, stuation, character, self-complacence, selfishness, foolish type and foolish action; humor and irony, language, replica, ingenuity, provebs, idioms; rood expressions, damnation and abusive language; repetition of the same words of phrases or extensive speech (Demirchizadeh A., 1941).

\section{Approaches to the characteristic fearures of the drama language}

There were expresses quite valuable thoughts about drama language. Itis worth to mention the thoughts and considerations of such Russian linguists as V.V.Vinogradov, A.I Yefimov, Azeri linguists such as A. Demirchzadeh, A.Akhundov, N.Abbasova, G.Kazımov, M.Mammadov and other ones. Too many dissertations, monoghraphies, articles were written about Ilyas Efendiyev's creativity in a whole (Elchin, 2000; Efendiyev T., 1999; Efendiyev T., 2002; Efendiyev A., 1996; Efendiyev A., 2000; Efendiyev A., 2002; Hajiyev D., 1983; Hajiyev A., 1986; Ismayılov Y., 1991; Garayev Y., 1987; Mammadov B., 1983; Mammadov M., 1968; Nabiyev B., 2000; Rahimli I., 1984; Seyidov Y., 1975; Safiyev A., 1999; Sultanlı A., 1964; Shahbazova S., 2002; Alizadeh M., 1990; Verdiyev V.S., 1984; Nasirov G., 1967). Ilyas Efendiyev's drama language was not a special topic of researches. Only I.B. Salmanov analysed the phraseological materials of the writer's drama pieces in his candidate dissertaton (Salmanov I., 1983). A.Salahova spoke about his prose pieces language andartistic features in her monogrphy named 'Ilyas Efendiyev's creativity poetry' (Salahova A., 1984).

The articles about the identity and style individuality of the dramatst's literaty language were written (Telmangızı A., 2003). M. Alizadeh writes that for the first time the 'lyrco-psychological drama' term was used in Azeri literaty 
critic lexis in connection with Ilyas Egendiyev's play named 'You are always with me' ('Sen hemishe menimlesen'). Up to this period the terms 'lyric prose', 'lyric drama-comedy' were not used (Alizadeh M., 1990). Transition to lyrico-psychological expression style is the main estetic feature of moving to foreground of the human factor in I.Efendiyev's dramaturgy. The idea content of his drama pieces were divided to three directions: 1) artistic presentation of moral and ethical values 2) artistic presentations of sociological problems 3) artistic presentations of history. At early stages of his creative activities the writer gave preference to social problems, and further to ethical and moral values. The approach to this issue can be divided to three groups:

1. The social life of Azerbaijan society in Ilyas Efendiyev's dramaturgy

2. The Azerbaijan ethical and moral problems in Ilyas Efendiyev's dramaturgy

3. Historical characters and events in Ilyas Efendiyev's dramaturgy

Rustication is one the main themes of Ilyas Efendiyev's drama pieces. Dramatic events take place in countryside. Rusticity creates drama stages in 'Spring waters' piece after Ilyas Efendiyev. The relations between Alkhan and Ughur are expressed by different language-speech tools. Let's pay attention to the example coming from people in Alkhan's speech: 'Hey, the son of my brother..., he says, one day the eagles gathered and chose one old eagle as an elder to themselves. The old eagle did all that is necessary for them. He fed their eyas with hot gazelle blood. He showed the way to the mad-brained. One day one young eagle returning from the faraway lands said to the elder eagle: 'Why have you imprisoned us to these narrow rocks? Do you even know how wide places and lofty rocks and are there in the world?! Then the elder eagle dropped a sigh, called the birds and said: 'My darlings, I have already grown old. My eyes do not see well. Choose a leader to yourselves'. The birds began to grumble and said 'We will fall short without you'. Worldly-wise old eagle said 'No, you are not right. Look! Choose this young eagle as an elder to yourselves. His wings are stronger than mine now. His eyes see farther'. The birds thought, then dropped a sigh and bore out what has said'. (Efendiyev İ., 1984).

This motive shows the writer's master use of folk wisdom, and its being in tune with the content of the work. The drama piece named 'The Atayevs' Family' ('Atayevler ailesi') deals with serious social ethic problems. I.Efendiyev reached high dramaturgy level due to this play, in which he used rich language tools. The speeches of every characters and heroes such as Khosrov Atayev, Ildirim Atayev, Dilshad, Reyhan, Mehrijan, Jahangir, Sadig Sadigov, Letafet, Shahsuvarov, Khudush, Aghaselim iffer from each other in accordance with their personal qualities. (Abbasova S., 2007). Ilyas Efendiyev's drama piece 'You are always with me' ('Sen hemishe menimlesen') is artistic understanding of moral and ethical problems. This play is based on lyrico-psycological mood (Efendiyev I., 2002).

As to Yashar Garayev, this work becoming a new word, successful occurrence in our literary life can considered to be a good intiative and experience on the perspective dramaturgy and creation of modern psychological theatre path (Garayev Y., 1972). In the drama piece named 'My sin' ('Menim gunahim') important moral and ethical problems are reviewed, the ways of solving these problems took a different approach by means of artistry. The language of the play differs by the bigness of the character. The moral and ethical norms of the society were put on the forefront in such Ilyas Efendiyev's drama pieces as 'Destroyed diaries' (1969), 'I cannot forget' (1968), 'Our strange destiny' (1988). Also in he play named 'In the crystal palace' (1982) the moral and ethical problems of society are considered. This drama is the best example of the lyrico-psychological style. In the work named 'A single oleaster tree' (1990) the moral and social duties issues are presented in a high artistic language (Efendiyev A., 2000).

The majority of Ilyas Efendiyev's drama pieces are on historical subject. One of such dramas is the play named 'The song stayed in the mountains' (1971). The researchers remind such an episode about the ideas and artistic qualities of the drama and the language aspects: I remember that in the latter half of the 1970s passengers of Baku underground - both those who spoke Russian and those who did not - were looking for such newspaper as 'Pravda', 'Komsomolskaya pravda', 'Izvestiya' on the stands. As if doing this they were saying: 'I am civilized, I am aristocrat, I am educated'. Once while playback of this stage I faced my course mates: 'If I had an opportunity I would send all in this wagonload directly to Azdrama on the Ilyas Efendiyev's play named 'The song stayed in the mountains' and then would ask: Which language is good? Yes, this is a strange episode of the past, but it is morality tale. Ilyas Efendiyev fought against with an intrinsic intentions that are not visible at first sight and directed against our language' (Tahirli A., 2003). Ilyas Efendiyes is such a great master of our nation who was not blinded by Soviet regime, did not fit literary stereotypes, frames and molds, and conversely benefiting from the opportunities of word and art, tried to tell the truth and show the deformities of the environment he lived in. In both historical and modern works of the dramatists this feature showed itself very clearly (Abbasova S., 2007). The play named 'Sweethearts 
coupling in the hell' (1989) is the first tragedy piece by I.Efendiyev. In this work the repression period troubles are shown in respect of innocent people. The historical drama named 'Khurshudbanu Natavan' lights up Natavan's life period and fight. The work named 'Sheykh hiyabani' (1986) is an interesting example of chronic genre. This drama contains characters based on the mother tongue guard. 'Yesterday I went to the Azeri language school opened in our street, and said to the teachers: Do not worry I will pay all the expences. Though Sari Merdan calls me capitalist. I am a capitalist or someone else, I do not know, but I see only my nation...' (Efendiyev I., 1989).

\section{Specific features of Ilyas Efendiyev's dramaturgy language}

Let's mention that determination of philosophic, ethic and aesthetic, linguistic, poetic colours of the literary text is one of the important terms (Valiyev K., 1986). One of the most effective and hard types of artistic creativity is drama genre. Ilyas efendiyev's drama pieces mean literary, imaginative ideas, mentality, logical and dynamic motions. Motion is consequent progress towards time, personality commitments, and demands of the life ideal. 'The dramaturgy in his creativity takes honorable place in my world, because in Ilyas's dramaturgy we see the follower of the great dramatist Jafar Jabbarly's traditions'. (Rahimov S., 1974).

Ilyas Efendiyev brought to our stage the wealth possessig a simple, clear and at the same time large lyricopsychological and emotional strength by his drama pieces. This is directly connected with the lanuage sources. There are considered to be two main sourses in formation of drama language: folk and art of great dramatiists J.Jabbarly. The first source is confirmed by the rich ethnographic lexis in drama language and phraseological layer with a broad sense of meaning. And the second one is a valuable influence of J.Jabbarly drama language syntaxis on I.Efendiyev's creativity. I. Efendiyev's laguage does not loose its reality; turning the mother tounge into the artistic language, materializing the aspects he learned from folk in this works J.Jabbarly's experience in syntaxis seem to be native to this creativity style. The great writer who passed though these sources created his own artistic language in Azerbaijan literature. In his drama pieces I. Efendiyev used 3 sources as in the other works: imagination, observation and experience. This three sources are directly connected to writer's creativty and artistic details. Because 'one of the important criteria for master's level determination are multi-function, specification simplicity, precision'. The author of this thought Kamil Valiyev tells that the writer uses one of these sources as a carpenter chooses a board fitting a size. Of course each writter first of all writes about himself, then he grows, works hard and imagination growth like a muscle, with aging he becomes an observer more and more... (Valiyev K., 1986). The artistic details in Ilyas Efendiyev's drama pieces are unbounded, natural, true-life, and are direct product of dramatist's deep observations. One the literary aspect drawing attenton in I.Efendiyev's dramaturgy is purposeful usage of a prologue and epilogue. They are repeated in dramatist's language. As in 'In the crystal palace' drama piece. For example:

Aynur (excitedly): Habib, oriole...

Habib: Oriole came to Baku

Aynur: When we have a daughter I will name her Oriole because oriole was the first to meet us in the garde when we met for the first time.

Habib: And what name will you give if we have a son?

Aynur: If we have a son will name him Habib.

Habib: Why Habib?

Aynur: Because I will to be jealous of my son over all other names exept Habib.

Habib: I wonder if 5 years later we will come to this park with our son or daughter? (Efendiyev I., 2005).

The characteristic features of national writer Ilyas Efendiyev's drama language are also explained by the name choosing principles. The stylish traditions of the names were also observed here. The passage processes of the phrasal words are the evidence of original expression style. There is an aim of style in a skill to purposely repeat the prologue and epiloguesa also. Each of these efforts is to strengthen the drama expression, and to give a new contentform to the utterance style. The sourse of this is folk and J.Jabbarly's realism, which beautifies I. Efendiyev's drama language.

\section{Reconciling of language and mastery issues in Ilyas Efendiyev's dramaturgy}

There are quiet many thoughts expressed about drama, dramaturgy, drama language and style. The multilayered language style aspects of Iyas Efendiyev's drama language was not almost studied in our philology. The research showed that the drama language of this great writer is distinguisged by meaningfulness in addition to being live and active. The master uses in his drama pieces such replicas, which are not limited by expression of only visible action, but also shows the works and actions happened before. Intercommunications between the diaogues are built in a 
such way that listeners clearly understand the following of whatis what they hear or can understand the connection between said expressions and the past. 'Little speech and broad content principle makes possible the connective, full and subject expression of the complex and multiple actions in drama language. The style capabilities of lexic unit are assimilated o iceberg in drama pieces. Only one part of iceberg is seen on the water surface, and seven parts are under the water and this gives the main power'. (Abbasova Namida., 1983). Being a literary type dramaturgy is considered to be very complex and hard field. Dramatist keep silence during the creativity prossess, his words and points of view are expressed by figures and characters. Undoubtly this is very hard to do. Each word, each sentence, live dialogues and replicas of figures ad characters should creat an impression of fullness. 'The demand to express many thoughts in a few words is related to dramatist first of all. The conciseness demand makes dramatist to use just one word instead of ten, but he should find such a word which will be able to replace those 10 ones' (Mammad Arif., 1968). Ilyas Efendiyev's drama language was of individual nature. In his many drama pieces the language and style genre is determined in accordance with demands. In Ilyas Efendiyev's drama language the methods and styles of characterizinig the figures are colorful:

1. the works, actions, movements of the figures are characterizing them: Alkhan (to Naringul): Shut up! I said you hundred times not to barge in when your husband talks! (Naringul blenched). Words are nothin without action. Give me an evidence, then see how I send them to hell! Madad. Evidence? Where should I find the evidence from? I am halfly educated, you are halfly educated. We both are not well-versed in calculations.

2. the ways of changing the meaning of the words, phrases and sentences characterize the figures: Gulu (to Najaf): My dear, why do you argue wit him? He says, 'A raven has 1002 plans for one nut'. The aim of all this is that no one should talk to Madad. Let his name be 'a farmer'and all day long deal with his own farm! Madad: "Look at yourselves instead of jeerinig the others".

3. the character of figure and heroes are revealed. Alkhan: Hey you, how long will you pickle a rod for own back? When will you pose something? The issue is not 'me' or 'you' There is not much left to reach kommunism.

It is just the beginning. 'Why someone gathered apples, but I broked the bushes'. Someone is bad, and you be good! If you do not betray the community, then everything will go its way! Let one person from 100 be a bad one. A drop of water will not affect tanker of oil! Madad: Talking like this you caused all these to us! I am working most of all but the most working days are given to Najaf! Gulu: demagogism solves nothing, my frind Madad. Everyone has a unique place.

Characteristic features are determined by relation of the characters and figures to each other, and to social environment also. Naringul: Hey man, you talk as if it is outrage in the country. So it goes, you give people an inch, they'll run all over you! It does not matter. I got over a labor, I can leave in such conditions. Let him care (look at Najaf with an ironic look) that he made his wife a lady, sitting at home, and he himself became Mr. Almurad's foreman, he is always whereon everything is good. Badal: My friend Ughur, isn't it possible for us to take all the income, and government gives a labour power? Najaf: You said foolish think! Could it be that we are separate from the government? 
charactristic features are dtermined by sencitive emotional conditions of characters. Najaf: Why did you swallowed your tounges? We try to solve such big problem. Khanmurad why do you keep silence and do not talk? Gulu, why can't we hear you? Naringul: It is a pity! If Gulu does not talk - the world will be in the crape! Badal: Oh my dear, small talks don't add up to love. (Efendiyev I., 2015.). .Efendiyev's drama language is a novator in accordance with its expression forms (Akhundov A., 2003). This innovation draw the attention of several great writers and scientists. The attitude of national writer Ismayil Shikhli: 'Ilyas Efendiyev is a writer who tries to express predatory taking place in people's perception and psychology, and makes psychological interference and contradiction to be the cemtral conflict' (Shıxlı I., 1980). The thoughts of national poet B.Vahabzadeh: 'The character should listen to its own inner voice, act in accordance with its nature, and its actions should proceed from the general logic of the work. From this point of view Ilyas Efendiyev's characters can convince us with their natural actions, their speeches'. (Vahabzadeh B., 1986). The thoughts of acaademic A.Akhundov can be also applied to Ilyas Efendiyev's language and mastery in dramaturgy: 1) New intonation quality, self intonation coming from depth of folk. This language is selected in accorance with sentence structure of drama language. 2) Intonation difference between traditional and new drama languages is connected with lexic factor - the characteristic of the word chosen. In the new drama language borrowed word and archaic words occur. 3) New drama language is differed from its predecessors by the successful solution of the typing problem in artistic language. 4) I.Efendiyev has the valuable credit of the both parts of typing in's artistic language - generalization and personalization. 5) Peculiar speech and spoken features. 'Speech in dranatist's stage plays means the life, thought and filling' (M.Arif, 1967). 6) New drama language differs from its predecessors by the strong national color also 7) New drama language also differs by its peculiar estitic princiles (Akhundov A., 2003).

The speech of I.Efondiyev's drama heroes is rich in metaphors. This develops and occures as the result of polysemanticism principles. Possessing this quality makes it possible to use word as an expressive and effective method. Metaphors system differs by its new forms in I. Efendiyev's drama pieces. Epithet draws attention in two groups in the creativity work: a) contrast epithets; b) oxymoron epithets. These types of epithets draw attention due to their originality and usage points in drama language. The author's searches and discovery reveals the new characteristic features of the described object and subject, gives them the colors and meaning according to his own feelings. Here all depends on the author's imagination, philosophy, fantsy, his point of views of the described object (Farida L., 2007). (This points were talked over in definite parts of the work). Generally, the lexis of Ilyass Efendiyev's drama pieces as a single system is determined by the following fields and groups: 1) semantic field;2) lexic-semantic word groups; 3) thematic groups; 4) communicative group; 5) kind-type group (synonyms raw, antonyms pairs, the total of all the meanings of multilingual words). The role of gestures and mimics in Ilyas Efendiyev's work of dramatic language is incomparable. In imagination of the objective realities of the world in the drama pieces he uses not only lexic units and syntactic constructions, but also non-language expressions such as movements, mimics, gestures, intonation, outline portrait lines, coverage and etc.

\section{Ilyas Efendiyev's achievements in development of lyrico-psychological drama language}

Drama is one of the main types of belles letters. The main sign of the drama is to show some exhausted characters, their actions, without author's speech, retelling, by expression in character's speech and actions. As in drama genre all occasions, expressions should be given in definte type of dialogues and monologues which in comparison with previous period are used less in modern dramaturgy, the language position, its role, seriousness and duties become more complicated; for this reason drama genre is considered to be one of the most complicated genres from the language point of view (Seyidov Y., 2008). The language never looses its critical role in literary work destiny. I.Efendiyev always feeled the new demands to the literary language in his creativity. He does not settle for the interviews about the general aspects of the literary language. He also covered retelling language, language of characters, stage language and other issues in his works and expressed individual original thought.

I.Efendiyev's drama language is a language fitted to certain size. The size is a dialect category in estethics, it is one of the regulative and normative principles of the artistic creativity. Sizelessness of a dramatist means his artistic merit forfeit. Drama language is determined in accordance with its motive and characteristic features. In particular the typical aspects of I.Efendiyev's drama language are expressivity, emotionality and psychological debth. The value and importance of the writer's language is directly determined by the development of literary language because literary language is grass-roots language, this language is more literate and improved form of the word. The history of all literary languages cultivated from the wealth of grass-roots language, he mastered folk art. For this reason the research of the writer's language is very important. Here the author clears up different aspects of creativity, the language methods used and individual character of materials (Yefimov A., 1954). 
Thus in a manner of speaking I.Efendiyev was a dramatist before starting to dramaturgy creativity; he had already grown into being a dramatist in his first prose on his way to dramaturgy. In his considerations on dramaturgy and prose I.Efendiyev drew special attention to the issues of modernity demands, life and heroes, conflict and character, tried to deepen and generalize his thoughts more in this direction. 'In XX century dramaturgy Ilyas Efendiyev following J.Jabbarly very successfully opened a new page in the history of theatre; founder of the lyricpsychological school he brought spring fun, romanticism, lyrico-psychological atmosphere to the stage. This school was formed with the play 'You are always with me', and now there are several great followers of it' (Efendiyev E., 2002). In I. Efendiyev's dramaturgy we see different types of repeated replicas. It is known that in drama pieces different commitments jar, the inner face of the relationship is opened. There are deep contradictions and gaps between families and family members. In revealing the contradictions in 'The Atayevs' family' play all methods of dialogue comesto help. The dialogue between Ildirim and Khsrov Atayev brothers as it is:

Ildirim Atayev (puts a newspaper on the table): From the very childhood we did not have any secrets from each other, Khosrov, to be honest your family life makes me sad.

Khosrov Atayev: Why? What is the reason?

Ildirim Atayev: We both fought for our nation, its big dreams, did not we?

Khosrov Atayev: Of course, you are right! Can it be another way?

Ildirim Atayev: And I know that there is nothing more sacramental than nation's morality!

Khosrov Atayev: Doubtless!

Ildirim Atayev: But it seems to me that your conviction caused deep contradiction between your work and family.

Khosrov Atayev: Resting on what do you say this?

Ildirim Atayev: Resting on what I see and here! (Efendiyev I., 2015).

The content and artistry characteristic, language and style of expression, expressionism, full replication, the richness of language and its styles used in dialogues and etc. in Ilyas Efendyev's play named 'The Atayevs' family give ground to say that being a unique master of lyrico-psychological drama in our literature the writer left deep dramaturgy heritage.

\section{Estimation aspects of Ilyas Efendiev's drama pieces and criteria of working on their language}

Ilyas Efendiyev defined several estiomation aspects of drama pieces: the problems he saw and heard in drama art can be groupped as following: These aspects are:

1. To avoid creation of strong tableau and deep conflicts. Sometimes it can be that dramatist solves the conflict laid in play in the second and third scene, and the rest four or five scenes he builds external stories, he is forced to talk about everutthing because he did not studies the main issues well (Efendiyev I., 1952). The illness named 'talking about everything', conflict affectation, conflict superficialism and repetition were affecting dramaturgy negatively. As to Ilyas Efendiyev, the stronger the conflict in play is, the stronger its efficiency will be. It is impossible to affect without a conflict. The best drama pieces of the world literature were composed on the basis of a conflict' (Efendiyev I., 1971).

2. To follow artificial decorations. The author wrote about this the following: «Our dramatists swim in very shallow places. They do not touch the deep, rotten places. And the conflicts and contradictions are generally not on the surface but at the depth. To reveal all these alonside with their weight requires not only courage but also power to do this » (Efendiyev İ., 1954).

3. First of all the reason of the other disadvantages is that very often we only try just to express the ideas of the people, and are not able to see their individual features and deep psychological signs. We forget that people's ideology, thoughts and findings, their morality style can not be unrelated to their personal characteristics, habits and traditions.

4. Live disadvantages are exaggeratedly ouput in drama pieces, outshine of the virtues, exaggerated ugly traits. Of course in I.Efendiyev's dramaturgic views positive and negative figures should be of equal power.

5. incomplete and weak description of a positive character. 'We should not idealize the postive hero for nothing, but should show him by hearing and feeling. His feelings and thoughts should be rich, live, natural and attractive' (Efendiyev I., 1959).

6. Impossibility to take as a basis for drama a clear and concrete issue. This shows that these writers can not study the rules and mission of the drama pieces well.

7. An effort to describe the life by simplifyng it. 'In drama pieces the figures are shown reducing intelectually and mentally. Their judgments and dialogue speeches are unbearably superficial and dry. The language of the 
dialogues is in bad shape.'

8. An effort to solve hard and complex issues by easy ways, weakness of coloration. I.Efendiyev considers his skill to express the coloration to be the basic terms of the writer's real talent. Ability to give coloration shows the drama as having week language and style.

9. tendency towards living conditions. In such kind of drama pieces the characters' state of mind and the ability to use language tools are weak.

Many ideas were expressed about the idea-literary and language-style creativity in drama pieces and other works of great Azeri writer Ilyas Efendiyev. Their characterization and making their minds rotten is very important from the poit of view of determination of the value give to his creativity and also showing of lifelikeness of his wors. Expression of the modernity feeling with the literary methods of the artistic language together the longevity and the importance of a work of art occures. 'The language of Ilyas Efendiyev's plays, the purity of stae language, its flexibility, compactness and expressiveness make positive impact. He chooses the words carefully. He uses a subtextual meanings skillfully; expresses the thoughts and feelings and hide them when the stage state ... Shafag and Sedef also had many thoughts and feelings. There are too litte words in dialogue.

The lack of words exactly and text compression creates conditions for good expression of thoughts and feelings. Dilogue was knitted from short senntences, small exclamation, question, dots and sience' (Mammadov Mehdi, 1965). Y.Seyidov writes: 'From the early times of the beginning of his creativity Ilyas Efendiyev was one of the selected writers to differ his language by its uniqueness. He is closely aware of potential of the rich Azeri language, he hears the style of people's speech, and the gradation of the words meaning in the sentence, he can find the only word. It is possible to learn much from the mastery of a writer...

The art is not created on its own. The appearance of psychologism, lyrico-psychological plays in a theatre first of all was a result of the close association with increase of the personality role in the developed society, strengthening of the humane treatment of people, and democracy enhancement' (Seyidov Y., 1975). I. Efendiyev were showing the importance of the requirement to the figurative language in drama pieces: 1) the language of dramatist did not differ from the characters' languages; 2) Personalization and typing of the real drama character's speech; 3) the figure's language should be different from the normal speaking. As to I.Efendiyev besides differing from lyric and epic genres by its form and content the drama genre is also characterized by the different language factors. As dramaturgy is directly connected with the stage and spectators, the master sharpens the language of composition more carefully; because alogside with being figurative and emotional the drama language should also differ with its simplicity and laconism. From the standpont of tje dramatist, in drama pieces the figure lives among people and takes part in social activity. For this reason the language of participants complements their thinking and personal factors, and reflects their relaition to the environment and society (Ismayllov Y., 1991).

The success of Ilyas started with 'Spring Waters' and began to grow more in his future lyrico-psychological plays. He gave us drama pieces each one better that the others considering the serious problems of the modern life. He became the lead dramatist of our head thatre. For approximately fifty years he undertook the weight of modern compositions demand in the thatres of our republic. Modernity feeling was very strong in his plays (Abbaszadeh H., 2006).

Showing the strong exaction to himself I. Efendiyev after public reviewing of his 'Erased diaries' drama he considered unreasonable the comment of authorised employee of the ideological department of the central committee, and said: 'I consider your comments to be unreasonable, and do not agree with them. As to me it is disgonest to badmouth for the composition written with good intentions. It is a wrong method to choose one single word or a sentence from the literary composition and to ascribe a meaning to it. I know very good what I compose and what I want to say to the audience' (Efendiyev E., 1996). In 'Spring Waters' composition the name of the play possess a particular literary experience and criticism. I am quiet open about the name of the composition being a stimulating factor to it, and that is sounds with literacy and poetry (Mirahmadov A., 1999). Ilyas Efendiyev creation doubtless is a separate stage in Azerbaijan literature. He brought his principles, subject, literary estethic definition and unique figures to dramaturgy. His dramaturgy is written in a poetic language. The lyricalpsychological tendency in dramaturgy is evident (Yusifli V., 2006). Attractiveness of Ilyas Efendiyev creation first of all is connected with the level of his language. His dramaturgy is rich in new topics, originam typic figures and inimitative style. The national writer M.Ibrahimov wrote that, artistic language has its own logarithm, and the write is responsible to study it during his whole life (Ibrahimov M., 1961). As the result of researching 
I.Efendiyev's drama language it is revealed which operaitions the master made on the drama language. The characteristic features of these operations starts with insight into corrections in manuscripts. These reviews show that the corrections on the language made by the great master, its connection with artistic figures fully meet all the language style norms. 'Drama develops more in the period of tense events, when the fight between new progressive social forms and the old ones strengthens. It is no coincidence that drama genre is considered to be the mosr hard type of the literature'. 'Drama language is a specific contamination of spoken and literary language'. (Sherba L.V., 1939). 'Drama pieces takes a special place among the artistic compositions, and the writer uses the most colorful speech tools because drama is more sensitive to differen occasions of social life, and is expressed by the language of the figures of this occasions (Kazımov Q., 1975.). The series of figures representing different problems differs by philosophy of life: historical characters, officials, ordinary people... These being the participants of drama are the right reflection of the main aim, description of morality, internal pain and general domestic problems (Allahverdiyeva Ş., 1999). The reserach of lyrico-psycological drama language make sense of different aspects of writer's creation, unique character of the language tools and materials used (Khrapchenko M.B., 1986).

Ilyas Efendiyev's dramaturgy which turned to be a separate style in the modern dramaturgy is characterized by expressing the important social-morality issues with high artistry during formation of each play. Ilyas Efendiyev's dramaturgy covers the moral which pose the modern people (Safiyev A., 1999). The poetry of figures' speech in Ilyas Efendiyev's drama language is observed in 'agile' actions, mimics and gestures, speech dynamics. This factor occurs not only in live scenes, actions and processes but also in expression of personal psychological and social dramatism of the figures and characters.

\section{Consilium:-}

The materials took place in the article give possibility to think that Ilyas Efendiyev's drama creativity has special place in the history of Azeri dramaturgy language development. As the result of researches there were reviewed the development ways of drama genre language and style on the basis of Ilyas Efendiyev's drama pieces, the specific features of this genre have been identified. The mastery of Ilyas Efendiyev's word use was revealed, the sense of meaning of heroes and characters speech was revealed.

We come to such a conclusion that the dialogue speech of Ilyas Afandiyev is a clear expression of the relationship of figures and characters, and idioms dominate in these speeches. Polemic dialogues with phraseological expressions create a unique environment in each replica, increase the meaning of the idea and the effectiveness of its styles. Thus, the transition from freestyle of word and word combination to phraseology can be treated as the skill of Ilyas Efendiyev in drama language. This passage can be characterized by his superiority to national phraseology andimaginative thought units instead of dry words usage. Because expressing the figures' and characters' thoughts by phraseology is more acceptable from the point of view of literary language, it is one of the main features due to which the nation and reader likes the imaginative work. The analysis of Ilyas Efendiyev's intensive word use in the drama pieces brought to the following results:

1. In Ilyas Efendiyev's drama pieces a word is an effective and suggestive example of imaginative speech;

2. The writer possesses his own dynamic system of characters typical of drama pieces which can be adapted with the development of events, word usage style and speech style;

3. The drama language being based on individual creativity features nd developing in grass-roots language possesses a power to develop stylish semantic position in some form or other;

4. Being a master of word and dalogue Ilyas Efendyev used the dialogue principles skillfully not generalizing and making them typical ones, generalized the characteristic events in a dialogue environment, and the most important - He has skillfully used such stylish methods as the choosing and replacing in creation of the replicas;

5. Being acquainted with the grass-roots language nuances very well the master used aphorisms to create deep meanings and confirm definite thoughts in relevant stylistic moments;

6. the literary generalization and personalization methods are also distinct in originality in figures' and characters' language created by the dramatist, there were revealed the skills of the writer in creation of each character's personal speech, movement and affectation;

7. It is possible to come to a conclusion that Ilyas Efendiyev is a real novator writer. From one side he creates new words and phrases, gives to them new meanings, and from the other side he finds out the literary forms and models, and etc. 


\section{Reference list:-}

1. Abbasova S. I. 2007. Efendiyev's Dramaturgy and Modernity. BSU.

2. Abbasova N. 1983. A Word in J.Jabbarly's Dramaturgy. Baku: The Writter 191 p.

3. Abbaszadeh H. 2006. 'An Eagle Flies to Heights'. The rich flower of the memory. Baku. 'Gerenfil' printing presses.

4. Allahverdiyev M.G. 1990. Drama Criticism and Modernity. Baku: Enlightenment 1990, 192 p.

5. Allahverdiyeva Sh. 1999. The Language of Jalil Mammadguluzadeh's Dramatic Pieces: Disertation synopsis of Cand. Sc. Baku

6. Alıshanlı Sh. 2017. Master's Subsistence Right. Issues of XX century literature. IV book. Baku: Science, 362 p.

7. Compositions of Akhundov M.F. 1951. 2nd vol. Baku.

8. Akhundov A. Language and Literature. 2003. In 2 vol. II vol., Baku: Genjlik.

9. Dadashov A. 2005. Dramaturgy of Independance Period. Baku, 216 p.

10. Demirchizadeh A. 1941. M.F. Akhundov about the Language and M.F. Akhundov's Language. Baku: Azerbaijan XMK printing presses, 1941, 42 p.

11. Elchin. 2000. Personality and Talent. Baku, UNDR. 96 p.

12. Elchin. 2002. The Second Life of Master (I. Efendiyev. Chronic of Five Years). Baku.

13. Efendiyev E. 1996. Ilyas Efendiyev. Baku, Ishig, 224 p.

14. Efendiyev E. 2000. Ilyas Efendiyev's Creativity. Baku: Elm, 310 p.

15. Efendiyev E. 2002. Ilyas Efendiyev. Biography indicator. Baku, 239 p.

16. Efendiyev I. 1984. Selected works. II vol., Baku: Yazıch1.

17. Efendiyev I. 2002. Selected works, in 7 volumes, I-VII vol., Baku, 448 p.

18. Efendiyev I. 1989. Our Strange Fortune. Plays, memoirs, novels. Baku, Yazichi, 536 p.

19. Efendiyev I. 2005. Selected works. In three volumes. I vol., Baku, 280 p.

20. Efendiyev I. 1952. For the High Art Writings «Literature Newspaper».

21. Efendiyev I. 1971. About Some Issues of Our Dramaturgy. Literature and Art Newspaper., 1971.

22. Efendiyev I. Azerbaijan Soviet Dramaturgy //Azerbaijan journal, 954, \# 7.

23. Efendiyev I. 1959. About Our Last Years Dramaturgy // Azerbaijan journal, \# 2

24. Efendiyev I. 2015. Selected Works. Book club, 536 p.

25. Efendiyev I. 2014. Selected Works. In 4 volumes. III vol. Baku: Tehsil, 656 p.

26. Aliyev M.I. 2009. Basis of Literature Theory. Baku, «Science and Education» printing presses, 480 p.

27. Efendiyev T. 1999. Historicity and Artistry in Romantic Dramaturgy. Baku.

28. Efendiyev T. 2002. Methods in Azerbaijan Dramaturgy. Baku: Elm, 512 p.

29. Eyyubgizi M. 2004. Romantism and Lyrico-psychological Tendecy. Linguistic Investigations (XX book), Baku: Azerneshr, $282 \mathrm{p}$.

30. Farida L. 2007. Epithets in Modern Azerbaijan Language. Baku: Ganun, 120 p.

31. Hajiyev D. 1983. Historical Drama in Azerbaijan Literature. Baku, Yazich1.

32. Hajiyev A. 1986. Author's Personality and Literary Compliance. Baku, 264 p.

33. Huseynova M. 2009. Lyrico-psychological method in Azerbaijan publishing in XX century and artistic individuality (monography). Baku: Elm, 292 p.

34. Ibrahimov M. 1961. Nationality and frontally realism. Baku, Azerneshr, $321 \mathrm{p}$.

35. Ilyas Efendiyev: Bibliography. 2014. / comp. by G.Safaraliyeva; edit. and publ. by K.Tahirov; Introduction Sh.Alishanli; Azerbaijan National Library. Baku, 512 p.

36. Ismayllov Y. 1991. Ilyas Efendiyev's Artistic Journey. Baku, Elm, 262 p.

37. Kazımov G. 1975. How did A. Hagverdiyev Worked on Drama and Prose Pieces Language? Special seminar on language. Writter and language. Baku: API publication.

38. Garayev Y. 1987. Ilyas Efendiyev. Baku, 'Bilik' society, 50 p.

39. Garayev Y. 1972. Our Stage and Contemporaries. Baku, Azerneshr.

40. Gurbanov A.M. 2005. Linguistic Analysis of Litetaty Text. Baku, 'Nurlan'.

41. Mammad Arif. 1968. Selected Works. 2nd vol., Baku.

42. Mammad Arif. 1967. Selected Works. In 3 vol., Azerbajan SSR Academy of Sciences publishing house, I vol.

43. Mammadov B. 1983. Xurshidbanu Natavan. Baku, Yazıchı.

44. Mammadov M. 1968. Estetic problems of Azeri Dramaturgy. Baku, Azerneshr.

45. Mammadova M. 2014. Typology of the characters in I.Efendiyev's drama pieces. Synopsis by PhD in filology. Baku, $26 \mathrm{p}$.

46. Mammədov Mehdi. 1965. On the life and art way. Azerneshr, Baku. 
47. Mammadova T. 2014 Psycologism in I.Efendiyev's prose. Baku: Science and Education, 160 p.

48. Mammadova Z. 2008. Characteristic Speech in Literaty Text. Baku: Elm, 188 p.

49. Mirahmadov A. 1999. Author Fascinated by Art.-Rich flower of memory. Baku, «Gerenfil» publishing house.

50. Nabiyev B. 2000. On hard ways. Baku, Elm, 779 p.

51. Rahimli I. 1984. Dramaturgy and thatre. Baku, Ishig.

52. Rahimov S. 1974. Double Winged. «Literature and Art» newspaper.

53. Salahova A. 1984. Poetry of I. Efendiyev's creativity. Baku, Yazichi, 136 p.

54. Seyidov Y. 1975. I.Efendiyev. Azerbaijan State Publishing, Baku, 235 p.

55. Publications by Seyidov Y. 2008. In 15 vol., VIII vol., Baku, Baku University publishing house, 678 p.

56. Safiyev A. 1999. Azerbaijan dramaturgy on modern stage (1960-1980 years). Baku: Ozan, 360 p.

57. Sultanl1 A. 1964. About the development history of Azerbaijan dramaturgy. Baku: Azerneshr.

58. Shahbazova S. 2002. Ilyas Efendiyev's Historical Drama. Baku, Aghrıdagh, 132 p.

59. Shixlı I. 1980. Years becomed memoirs. Baku, Yazichi, 366 p.

60. Tahirli A. 2003. Prose Writer and Dramatist's Lyrics. 'Literature newspaper' \# 38 (3372).

61. Telmangızı A. 2003. Artistic Language Features and Method Individuality. «Culture World », VII edition. Baku: Nurlan.

62. Tinayeva A. 2006. Lyrico-psycological Method Direction in Prose of Modern Azerbaijan. C.ph.sc. dissertation. Azerbaijan National Science Academy. Literature Institute after Nizami. Baku, 129 p.

63. Vahabzadeh B. 1986. Light to deep layers. Baku, Yazichi, 320 p.

64. Valiyev K. 1986. The Magic of the Word. Baku, Yazichi, 303 p.

65. Yusifli V. 2006. Rich lower fragnance.- The rich flower of your memory. Baku, «Gerenfil» publishing house.

66. Zeynallı G. 2015. The Points of Use of Lyrico-Psycological method in Ilyas Efendiyev's Novels // Sumgayit State University - Science New - Department of Social and Human Sciences. 11th vol., \#4, 25-28 p.

67. Alizadeh M. 1990. The Problem of Hero in Lyrico-Psycological Drama (adapted from Ilyas efendiyev's creativity): Synopsis of disseration after the cand. of philolgy sciences. Baku, $23 \mathrm{p}$.

68. Verdiyev V.S. 1984. The problem of character of Azerbaijan dramaturgy (70-80 years.). Synopsis of disseration after the cand. of philolgy sciences. Baku, $23 \mathrm{p}$.

69. Vinogradov V.V. 1959. About the language of belles-lettres. M., Goslitizdat.

70. Efimov A.I. 1954. About the languae of belles-lettres. M., Gosuchpedizdat, 1954.

71. Kojevnikova K. 1970. Spontaneous Spoken Language in Epic Prose. Prague. Karlov’s University publishing house.

72. Nasirov G. 1967. Ilyas Efendiyev's Artistic Journey. Synopsis for competition of science degree of cand. of philology sciences. Baku. 23 p.

73. Politova L.V. 1992. Literary Text as a Source of Spoken Language Study. AKD, SPb.

74. Salmanov I. 1983. Language and Stylistic Features of Lyrico-Psycological Drama in Azerbaijan Literature (on the basis of phraseology of Ilyas Efendiyev's dramaturgy). Synopsis of diss. of cand. ofphilology sciences, Baku, $23 \mathrm{p}$.

75. Sibagatov R. 1983. G.Ellipsys in the System of Predicative Relation Idioms \«ST», Baku, \# 6.

76. Khrapchenko M.B. 1986. Belles-lettres Language \ Literary theory investigations. M..

77. Sherba L.V. 1939. Moder Russian Literary Language II 'Russian Language in School”, \# 4. 